\title{
Environmental and zooplankton parameter changes during the drying of a saline shallow temporary lake in central Argentina
}

\author{
Alicia María Vignatti ${ }^{1, *}$, Gabriela Cecilia Cabrera ${ }^{1,2}$, Maila Canosa ${ }^{1}$ and \\ Santiago Andrés Echaniz ${ }^{1}$
}

Edited by

Juan Carlos Salcedo-Reyes

(salcedo.juan@javeriana.edu.co)

1. Faculty of Natural and Exact Sciences, Department of Biological Sciences,

Avenida Uruguay 151, 6300, Santa Rosa,

La Pampa, Argentina

2. CONICET (Consejo Nacional de Investigaciones Científicas y Técnicas), Avda. Godoy Cruz 2290, 1425, Ciudad Autónoma de Buenos Aires, Buenos

Aires, Argentina.

*aliciavignatti@exactas.unlpam.edu.ar

*aliciavignatti@cpenet.com.ar

Received: 23-01-2017

Accepted: 17-08-2017

Published on line: 20-09-2017

Citation: Vignatti AM, Cabrera GC, Canosa M, Echaniz SA. Environmental and zooplankton parameter changes during the drying of a saline shallow temporary lake in central Argentina, Universitas Scientiarum, 22 (3): 177-200, 2017. doi: 10.11144/Javeriana.SC22-2.eazp

Funding:

$\mathrm{N} / \mathrm{A}$

Electronic supplementary material: $\mathrm{N} / \mathrm{A}$

OPEN ACCESS

\begin{abstract}
Central Argentina has numerous saline lakes sustained by groundwater sources and rainfall. These lakes are temporary and experience significant changes in water level and salinity, depending on wet and dry climate cycles. This study aims to investigate the scarcely known dynamics of environmental and zooplankton parameters during the drying phase of one of these lakes. Monthly samples were taken from December 2012 to July 2013 in the Ojo de Agua Uriburu lake, previous to its drying. At the beginning of the study, the lake's depth was $0.7 \mathrm{~m}$ and its salinity was $16.65 \mathrm{~g} \mathrm{~L}^{-1}$, later, in July, its depth decreased to $0.06 \mathrm{~m}$ and its salinity increased to $92.9 \mathrm{~g} \mathrm{~L}^{-1}$. Zooplankton species richness was low (three crustaceans and three rotifers), with Boeckella poopoensis and Moina engeniae dominating in the system. Maximum density and biomass were attained by the two dominant species in April (318.5 ind $\mathrm{L}^{-1}$ and $3029.1 \mu \mathrm{g} \mathrm{L}^{-1}$ dry weight; and 242.4 ind $\mathrm{L}^{-1}$ and $1530.4 \mu \mathrm{g} \mathrm{L}^{-1}$ dry weight, for B. poopoensis and M. engeniae, respectively), and no correlation was found between these parameters and salinity. Maximum average body lengths for both species were observed in the last months of sampling (M. engeniae: $1020 \pm 84.2 \mu \mathrm{m}$ and B. poopoensis: $1348.8 \pm 89.0 \mu \mathrm{m}$ ). At this point of the study, neither juvenile nor larval stages were found. The increase in average body size is, arguably, the result of increased salinity in the system through a negative effect on reproduction. Because this lake reached hypersalinity, its ecological dynamics are unique among those of other temporary, saline lakes that dried in central Argentina. Similar studies on other temporary ecosystems are needed to increase the information on these little known ecological aspects.
\end{abstract}

Keywords: temporary lake; saline lake; hydroperiod; zooplankton; Boeckella poopoensis; Moina engeniae.

\section{Introduction}

Temporary lakes contain water during periods as short as a few months and up to several years (Schwartz \& Jenkins, 2000). These lakes are globally distributed, and their sizes range from a few square meters to hundreds of 
hectares (Williams, 1987; 2002; Schwartz \& Jenkins, 2000). Many of these ecosystems are disappearing because of anthropic activity, including their transformation into agricultural fields (Belk, 1998; Williams, 2002; Jenkins et al. 2003; Eitam et al. 2004). The transformation and destruction of these ecosystems leads to species loss, thus significantly affecting local biodiversity (Waterkeyn et al. 2008).

Most water bodies in La Pampa province, a central semiarid region of Argentina, are shallow (maximum depth $<3 \mathrm{~m}$ ), temporary lakes. These lakes occur in arheic basins, where surface runoff flows unpredictably due to lack of drainage patterns (Mann, 2002; World Meteorological Organization, 2012; Meybeck et al. 2013), and they are formed by phreatic input and, to a lesser extent, by rainfall (Dornes et al. 2016).

Most of the Pampean temporary lakes are saline; with ions such as $\mathrm{Na}^{+}$and $\mathrm{Cl}^{-}$predominating in their composition (Echaniz, 2010), and concentrations of dissolved solids exceeding $3 \mathrm{~g} \mathrm{~L}^{-1}$ (Hammer, 1986). An important characteristic of saline ecosystems is that changes in water level cause considerable modifications of their physical and chemical parameters; thus, exerting major physiological constraints on the inhabiting biota (McCulloch et al. 2007). Further, salinity is an environmental variable with a strong influence on zooplankton. Salinity level is inversely associated with species richness and has been documented as an environmental stressor (Herbst, 2001). When salinity decreases, species richness increases (Wurtsbaugh \& Berry, 1990; Green, 1993; Williams, 1998; Hall \& Burns, 2003; Ivanova \& Kazantseva, 2006) and vice versa (Green, 1993; Hall \& Burns, 2003; Kipriyanova et al. 2007). Zooplankton communities play an important ecological role in shallow temporary lakes because these organisms occupy different niches in aquatic food webs, and they contribute to element recycling and energy transfers (El-Shabrawy et al. 2015). Thus, changes in zooplankton community composition can alter characteristics of a lake, such as water transparency, phytoplankton composition, and chlorophyll-a concentration (Jenkins et al. 2003; Echaniz, 2010).

Several ecological aspects of temporary lakes have been studied in Australia (Williams et al. 1998; Bayly, 2001; Roshier et al. 2001), North America (Smith et al. 2003; Wallace et al. 2005), and Europe (Mura \& Brecciaroli, 2003; Frisch et al. 2006). In Argentina, temporary lakes are common, yet their ecology has received little attention. Most of the studies on Argentine temporary lakes have been conducted in aquatic ecosystems, located in La Pampa Province, and many of them took place during annual cycles characterized by a certain hydrological stability. Therefore, many aspects of their ecology, under 
relatively limited salinity variation, are now documented (Echaniz et al. 2013a; b; 2015). Other studies have also compared the conditions recorded in different periods (annual cycles) for a given lake and showed differences in physical and chemical variables, as well as in zooplankton biological traits (Echaniz \& Vignatti, 2011; Echaniz et al. 2006; 2012; 2013a; b; 2016; Vignatti et al. 2012a). Moreover, three studies conducted in La Pampa showed changes in limnological parameters and zooplankton traits during the filling or drying phases of temporary, subsaline and saline lakes, (Echaniz \& Vignatti, 2010; Vignatti et al. 2012a; b). To the day, little is known about the ecological dynamics of species inhabiting a temporary water body as it experiences environmental transitions. Species replacement is one of such ecological dynamics, and it involves the emergence of organisms from sediments (resting egg bank) (Williams, 1987; Belk, 1998; Schwartz \& Jenkins, 2000; Vignatti et al. 2012b). This issue is of primary interest, because species assemblages recorded in the lakes of central Argentina differ from those in other continents. Particularly, many endemic species to the Neotropical region are represented (Adamowicz et al. 2004; Echaniz, 2010; Echaniz et al. 2006; 2012; Vignatti, 2011; Vignatti et al. 2012b; 2016), and ecological knowledge about them is relatively scarce.

The present study aimed to describe the variation in species composition, and in three biological parameters (i.e. individual density, biomass, and body size) of a zooplankton community inhabiting a saline, shallow, and temporary lake, that underwent drying in La Pampa Province. Further, the relationship among a set of environmental and biological parameters of the lake was investigated. Specifically, this study addressed two hypotheses: i) the increase in salinity produced by water evaporation has a negative effect on zooplankton richness, density, and biomass; and ii) because the lake lacks predatory fish, due to its saline and temporary nature, zooplankton is dominated by species with large body size.

\section{Materials and methods}

\section{Study area}

The Ojo de Agua Uriburu lake ( $36^{\circ} 31^{\prime} \mathrm{S}, 63^{\circ} 53^{\prime} \mathrm{W}$ ) is located in the east of La Pampa Province (central Argentina), at the western boundary of the Pampa Plains phytogeographic region (Fig. 1). The lake was formed in an arheic basin and is sustained by phreatic inputs and rainfall. Water level fluctuations produce large movements of the coastline. Therefore, its outline is a beach with patches of halophytic vegetation. 


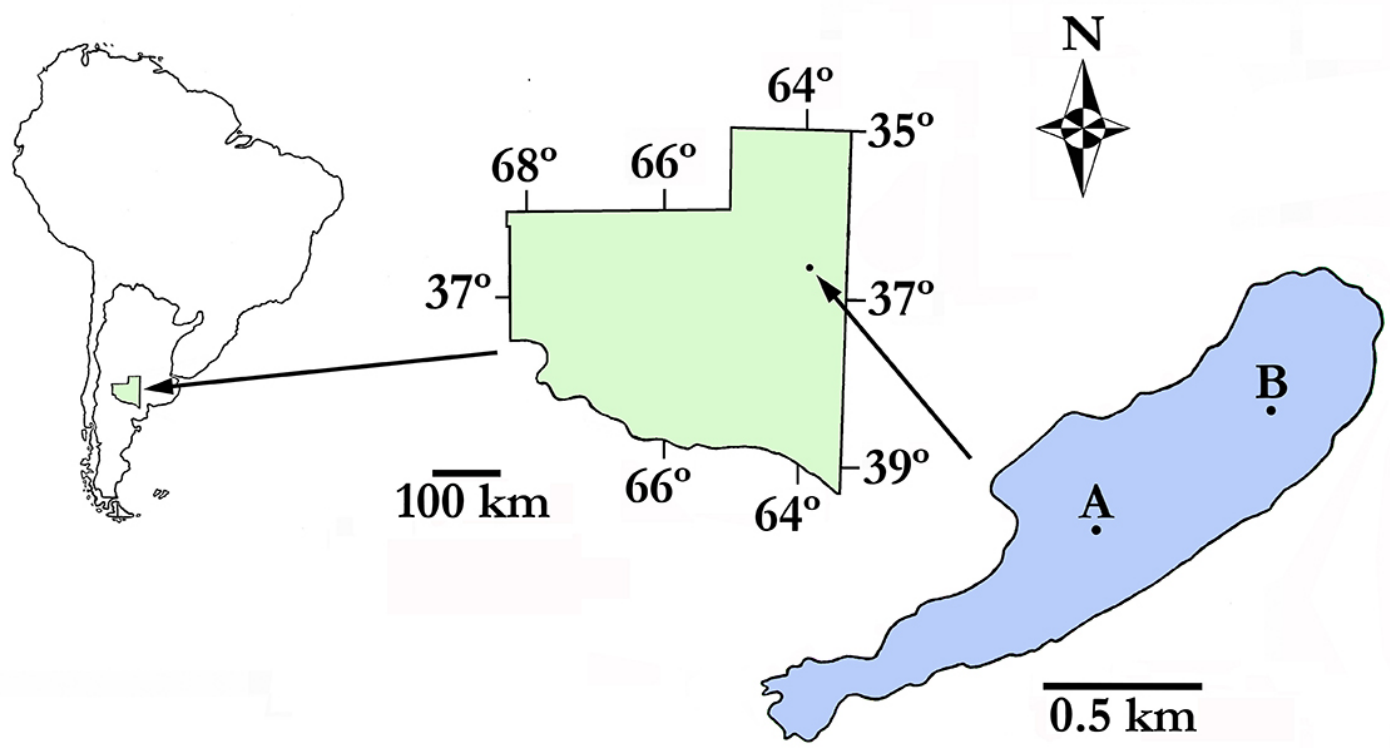

Figure 1. Geographic location of the Ojo de Agua Uriburu lake in the province of La Pampa (central region of Argentina). A and B indicate sampling sites. The outline denotes the morphometric dimensions recorded in December 2012.

The lake is surrounded by fields where cereals and oilseeds are cultivated, and, to a lesser extent, are used as pasture for cattle. This lake does not host any aquatic vegetation or fish.

At the beginning of the study period (December 2012), the maximum length of the lake was $2351 \mathrm{~m}$, its maximum width was $614 \mathrm{~m}$, and its maximum area was $86.8 \mathrm{ha}$. These parameters gradually decreased until complete lake drying up.

\section{Field and laboratory work}

Monthly samples were taken from December 2012 to July 2013 (the lake dried up after the last sampling). Samples were taken at two sites along the lake's major axis (Fig. 1). At each sampling spot, the following environmental variables were measured: water temperature, dissolved oxygen concentration (Lutron ${ }^{\circledR}$ OD 5510 oxygen meter), water transparency (Secchi disk, $22 \mathrm{~cm}$ in diameter), and $\mathrm{pH}$ (Cornning ${ }^{\circledR} \mathrm{PS} 15 \mathrm{pH}$ sensor). Water samples were taken and kept refrigerated until laboratory analysis. Moreover, two 20-liter 
quantitative zooplankton samples were taken at each sampling site. Given the shallow depth of the lake, samples were taken with graduated pails, that integrated the water column, and were then filtered through a net with a mesh size of $0.04 \mathrm{~mm}$. In addition, at each sampling spot, a qualitative sample was also taken with a similar net. All samples were anesthetized with $\mathrm{CO}_{2}$ and kept refrigerated until fixation. Afterward, they were deposited in the collection of the Facultad de Ciencias Exactas y Naturales de la Universidad Nacional de La Pampa.

Water samples were taken for the following analyses: salinity determination, through the gravimetric method with drying at $104{ }^{\circ} \mathrm{C}$ (APHA, 1992); chlorophyll-a concentration, determined by extraction with aqueous acetone and spectrophotometry (Arar, 1997); and concentration of suspended solids (total, organic, and inorganic), determined by weighing Microclar ${ }^{\circledR}$ FFG047WPH filters, drying at $\left(103^{\circ} \mathrm{C}-105^{\circ} \mathrm{C}\right)$ to a constant weight, and calcining at $550^{\circ} \mathrm{C}$ (EPA, 1993). Water samples were taken twice during the study period (January and July), to determine ionic composition.

Macro and microzooplankton (Kalff, 2002) counts were made under stereoscopic and conventional optical microscopy in Bogorov and Sedgwick-Rafter chambers, respectively. 1-mL aliquots were prepared using a Russell sub-sampler. Samples were homogenized by shaking. Zooplankton density was obtained by counting the number of individuals (ind) per volume unit, expressed as ind $\mathrm{L}^{-1}$. Zooplankton biomass (expressed as $\mu \mathrm{g} \mathrm{L}^{-1}$ ), was determined based on measurements of 30 specimens, of each species and from all stages, made with a micrometric Arcano ${ }^{\circledR} 10 x$ eyepiece. For crustaceans, available formulae relating total length to dry weight were used (McCauley, 1984; Culver et al. 1985). For rotifers, the Ruttner-Kolisko's method (1977) was employed. With this method, a specimen's volume was estimated, assuming that the geometric formulae provide an accurate proxy (McCauley, 1984). Subsequently, the volume estimate allowed for fresh weight calculation (assuming a specific gravity of 1) and its subsequent conversion to dry weight (assuming a dry wet ratio of 0.05) (Ruttner-Kolisko, 1977; McCauley, 1984).

The obtained data followed neither normality nor it revealed variance homoscedasticity, thus non-parametric Spearman's rank correlation coefficients were calculated (Zar, 1996). Software packages Past (Hammer et al. 2001) and Infostat (Di Rienzo et al. 2010) were employed for statistical analyses. 


\section{Results}

\section{Environmental variables}

At the beginning of the study, in December 2012, the depth of the lake was around $0.7 m$ and its salinity barely exceeded $16 \mathrm{~g} \mathrm{~L}^{-1}$. However, in July 2013, its depth decreased to $0.06 \mathrm{~m}$, and its salinity increased above $92 \mathrm{~g} \mathrm{~L}^{-1}$, before the lake dried up completely (Fig. 2). The correlation between lake depth and salinity was high $\left(r_{s}=-0.97 ; p=0.0005\right)$.

Water chemical composition analyses revealed that $\mathrm{Cl}^{-}$and $\mathrm{CO}_{3}{ }^{2-}$ were the predominant anions, with concentrations exceeding 20000 and $14000 \mathrm{mg} \mathrm{L}^{-1}$, respectively, and that $\mathrm{Na}^{+}$predominated among the cations, exceeding a concentration of $21000 \mathrm{mg} \mathrm{L}^{-1}$. Divalent cations $\left(\mathrm{Ca}^{2+}\right.$ and $\left.\mathrm{Mg}^{2+}\right)$ were present in low concentrations, and thus total hardness of the water was relatively low (Table 1). Furthermore, mean water $\mathrm{pH}$ was of 9.74 and fluctuated little along the study period (Table 1). Throughout the study period, mean water temperature was of $19.74{ }^{\circ} \mathrm{C}$ (Table 1); water temperature showed an overall steady decline throughout the sampling period. A maximum water temperature of $25.7^{\circ} \mathrm{C}$ was recorded in January and a minimum of $10.9^{\circ} \mathrm{C}$ in July. Mean dissolved oxygen concentration in water was high, around $8 \mathrm{mg} \mathrm{L}^{-1}$ (Table 1), and fluctuated from a minimum of $6.7 \mathrm{mg} \mathrm{L}^{-1}$ (February) to a maximum of $9.9 \mathrm{mg} \mathrm{L}^{-1}$ (July) (Fig. 3). A correlation was found between these two parameters $\left(r_{s}=-0.87 ; p=0.0077\right)$.

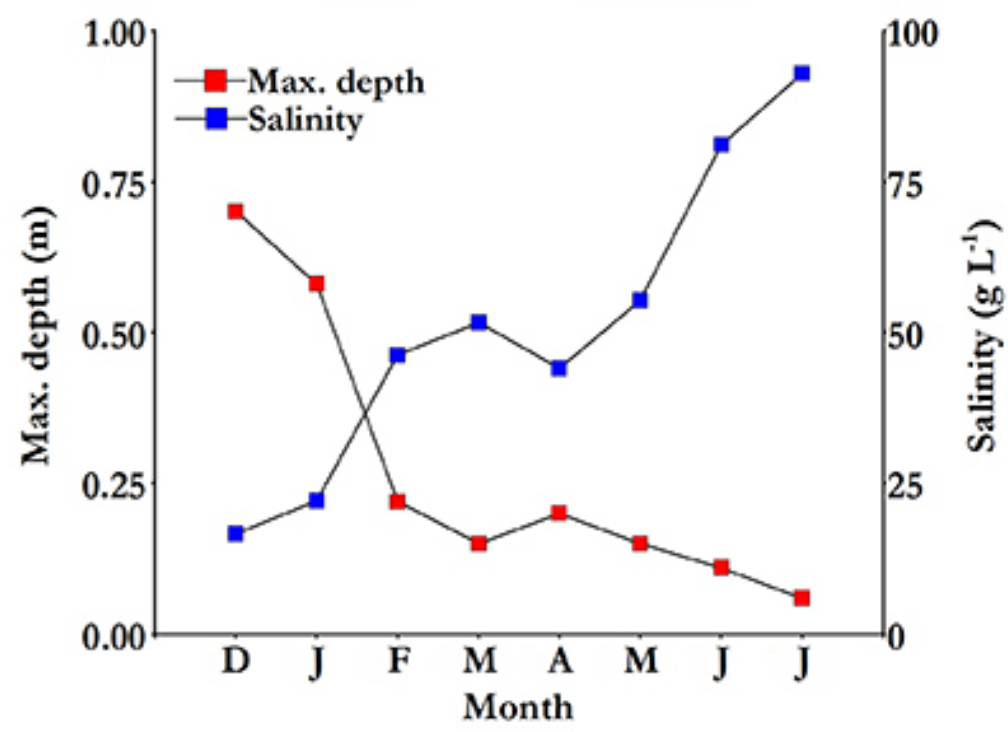

Figure 2. Maximum water depth and salinity variation in the Ojo de Agua Uriburu lake between December 2012 and July 2013. 


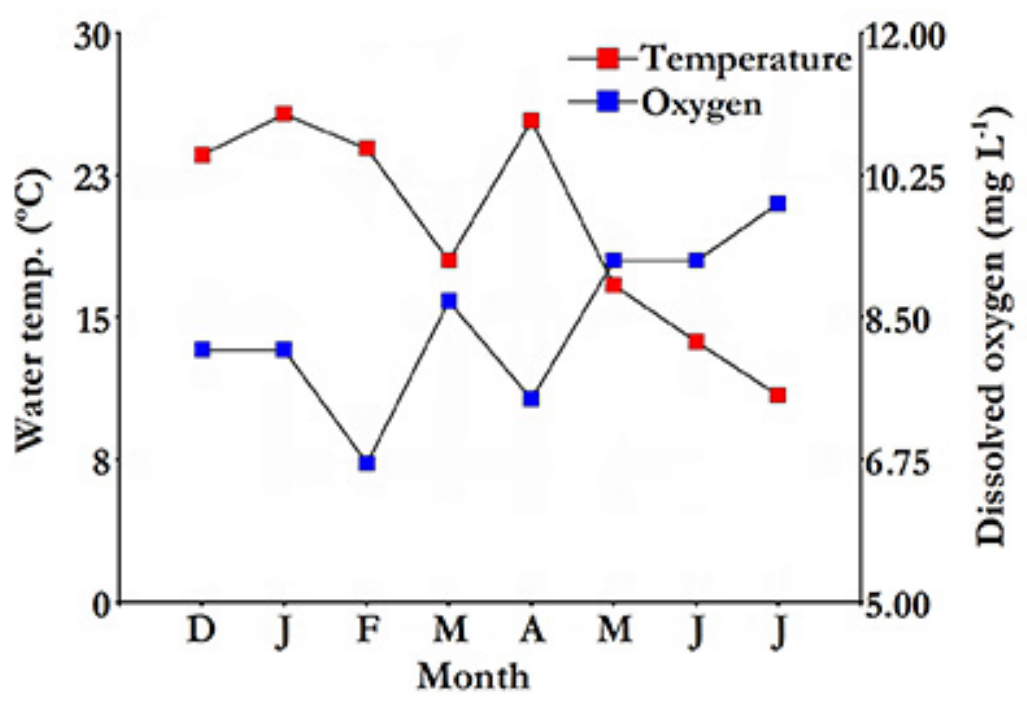

Figure 3. Water temperature and dissolved oxygen concentration variation in the Ojo de Agua Uriburu lake between December 2012 and July 2013.

Water transparency was always low (Table 1), with a maximum of $0.22 \mathrm{~m}$, recorded in February (Fig. 4). Phytoplankton chlorophyll-a concentration was reduced at the beginning of the study but experienced a marked autumn peak, reaching $104.13 \mathrm{mg} \mathrm{m}^{-3}$ in April, followed by a sharp decline in March (Fig. 4). A significant correlation was found between water transparency and chlorophyll-a concentration $\left(\mathrm{r}_{s}=-0.81 ; \mathrm{p}=0.0184\right)$.

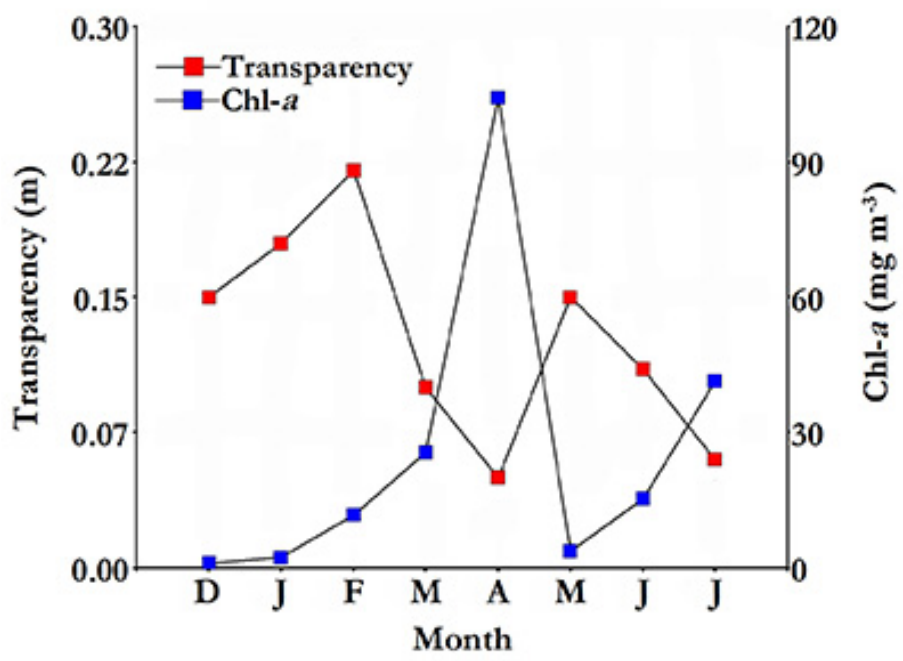

Figure 4. Water transparency and chlorophyll- $a$ variation in the Ojo de Agua Uriburu lake between December 2012 and July 2013. 
Table 1. Mean and standard deviation of the water physicochemical variables measured in the Ojo de Agua Uriburu lake between December 2012 and July 2013.

\begin{tabular}{|c|c|}
\hline Physicochemical variables & $\begin{array}{c}\text { Mean } \\
\text { ( } \pm \text { standard deviation) }\end{array}$ \\
\hline Salinity $\left(g L^{-1}\right)$ & $51.27 \pm 24.42$ \\
\hline Water temperature $\left({ }^{\circ} \mathrm{C}\right)$ & $19.74 \pm 5.32$ \\
\hline Dissolved oxygen $\left(m g L^{-1}\right)$ & $8.43 \pm 0.97$ \\
\hline Transparency $(m)$ & $0.13 \pm 0.05$ \\
\hline Chlorophyll- $a\left(m g m^{-3}\right)$ & $25.66 \pm 32.28$ \\
\hline $\mathrm{pH}$ & $9.74 \pm 0.21$ \\
\hline Total suspended solids $\left(m g L^{-1}\right)$ & $506.25 \pm 537.59$ \\
\hline Inorganic suspended solids $\left(m g L^{-1}\right)$ & $380.03 \pm 357.26$ \\
\hline Organic suspended solids $\left(m g L^{-1}\right)$ & $126.22 \pm 197.92$ \\
\hline $\mathrm{CO}_{3}^{2-}\left(m g L^{-1}\right)$ & $14480.00 \pm 17083.70$ \\
\hline $\mathrm{HCO}_{3}^{-}\left(m g L^{-1}\right)$ & $2250.00 \pm 3182.00$ \\
\hline Total hardness $\left(m g L^{-1}\right)$ & $45.30 \pm 4.60$ \\
\hline $\mathrm{Cl}^{-}\left(m g L^{-1}\right)$ & $20836.00 \pm 18732.70$ \\
\hline $\mathrm{SO}_{4-}^{2}\left(m g L^{-1}\right)$ & $2600.00 \pm 707.10$ \\
\hline $\mathrm{Ca}^{2+}\left(m g L^{-1}\right)$ & $17.70 \pm 2.40$ \\
\hline$M^{2+}\left(m g L^{-1}\right)$ & $6.70 \pm 0.60$ \\
\hline$K^{+}\left(m g L^{-1}\right)$ & $175.50 \pm 211.40$ \\
\hline $\mathrm{Na}^{+}\left(m g L^{-1}\right)$ & $21380.00 \pm 16800.90$ \\
\hline
\end{tabular}

Throughout the study period, the average concentration of total suspended solids was higher than $500 \mathrm{mg} \mathrm{L}^{-1}$ (Table 1). The correlation between water transparency and suspended solids concentration was high $\left(r_{s}=-0.84 ; p=0.0096\right)$. Solids of inorganic origin were dominant and represented $75 \%$ of the total solids, and organic solids accounted for the remaining $25 \%$ (Table 1). Both solid types showed a strong peak in autumn, especially in April, exceeding $1730 \mathrm{mg} \mathrm{L}^{-1}$ altogether. 


\section{Zooplankton community composition and parameters:}

Six zooplankton species were recorded in the Ojo de Agua Uriburu lake throughout the six-month study period. A maximum species number of five was observed in February, and it declined as lake drying proceeded, so that, only one species was recorded in July.

The copepod Boeckella poopoensis (Marsh, 1906) was found in each month, from December to July, even when salinity rose above $90 \mathrm{~g} \mathrm{~L}^{-1}$. Whereas the cladoceran Moina engeniae (Olivier, 1954) was registered between December and May (Table 2), disappearing from the lake when salinity exceeded $55 \mathrm{~g} \mathrm{~L}^{-1}$. Three rotifer species were first registered in the middle of summer (February), with Brachionus plicatilis (Müller, 1786) surviving the longest in the lake, almost until late autumn (Table 2).

Total average density and biomass values of the zooplankton community in Ojo de Agua Uriburu, were of $347.34( \pm 341.29)$ ind $\mathrm{L}^{-1}$ and 1602.33 ( \pm 1 485.55) $\mu \mathrm{g} \mathrm{L} \mathrm{L}$, respectively. Both parameters were correlated $\left(\mathrm{r}_{s}=0.86 ; p=0.0072\right)$ and showed a strong peak at the beginning of autumn (April), when density was as high as 1037.25 ind $\mathrm{L}^{-1}$, and recorded biomass was $4912.3 \mu \mathrm{g} \mathrm{L}^{-1}$.From May on, both zooplankton density and biomass were severely reduced (Fig. 5 and 6). No correlations were found between zooplankton total density or biomass and the assessed environmental parameters.

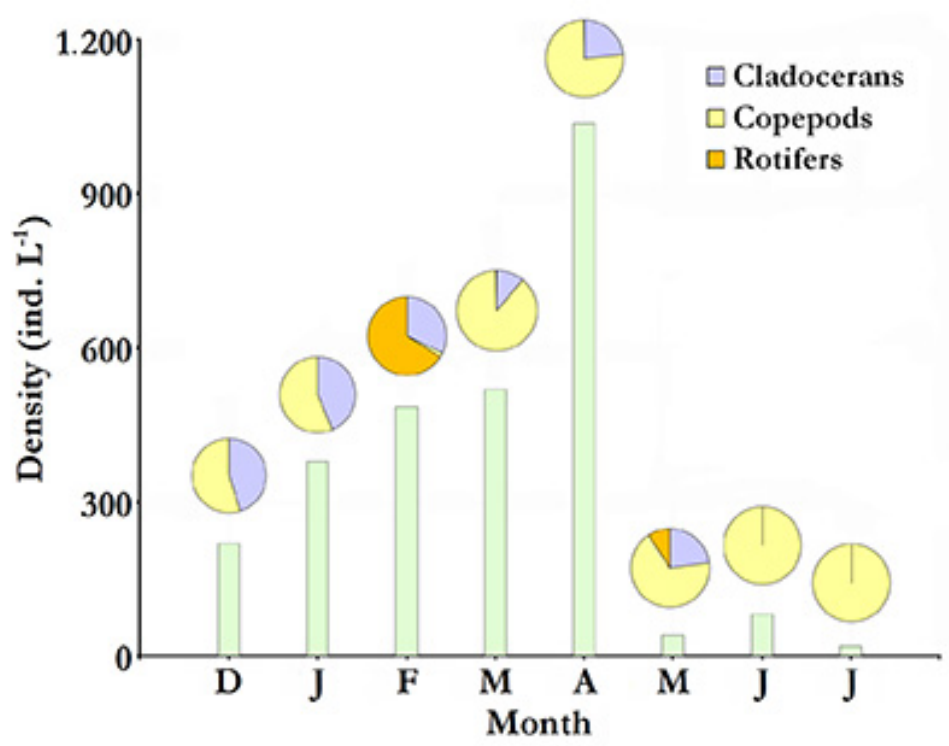

Figure 5. Total zooplankton density at each sampled month from December 2012 to July 2013 (bars) with relative contributions by taxonomic group (pie charts above bars) in the Ojo de Agua Uriburu lake. 
Table 2. Zooplankton species and months when they were recorded in the Ojo de Agua Uriburu lake.

\begin{tabular}{|c|c|c|c|c|c|c|c|c|}
\hline & & & & & & & & \\
\hline & D & $\mathrm{J}$ & F & $\mathbf{M}$ & $\mathbf{A}$ & $\mathbf{M}$ & $\mathrm{J}$ & $\mathrm{J}$ \\
\hline Cladocerans & & & & & & & & \\
\hline $\begin{array}{l}\text { Moina engeniae } \\
\text { Oliver, } 1954\end{array}$ & & & & & & & & \\
\hline Copepods & & & & & & & & \\
\hline $\begin{array}{l}\text { Boeckella poopoensis } \\
\text { Marsh, } 1906\end{array}$ & & & & & & & & \\
\hline $\begin{array}{l}\text { Metacyclops mendocinus } \\
\text { (Wierzejski, 1892) }\end{array}$ & & & & & & & & \\
\hline Rotifers & & & & & & & & \\
\hline $\begin{array}{l}\text { Hexarthra fennica } \\
\text { (Levander, 1982) }\end{array}$ & & & & & & & & \\
\hline $\begin{array}{l}\text { Brachionus plicatilis } \\
\text { Muller, } 1786\end{array}$ & & & & & & & & \\
\hline $\begin{array}{l}\text { Bracbionus dimidiatus } \\
\text { Bryce, } 1931\end{array}$ & & & & & & & & \\
\hline
\end{tabular}

For most of the study period, copepods accounted for the largest fraction of zooplankton density and biomass in Ojo de Agua Uriburu in five out of the six months that lasted the sampling (Fig. 5 and 6).Remarkably, rotifers accounted for the largest fraction of the zooplankton density in the lake in February (Fig. 5), as evidenced by an abundance peak of 305.8 ind $\mathrm{L}^{-1}$ for Hexarthra fennica (Levander, 1892), while, in the same month, the largest contribution to a biomass of $726.6 \mu \mathrm{g} \mathrm{L}^{-1}$ was made by the cladoceran M. engeniae (Fig. 6). During the first four months, parthenogenetic, ovigerous M. engeniae females were registered. These females accounted for $34 \%$ and $6 \%$ of the population density in January and April, respectively. From May on, no single $M$. engeniae individual bore eggs.

Among copepods, the species B. poopoensis dominated in the lake. Both $B$. poopoensis adults and copepodites were present throughout the study with anaverage density of 114.8 ind $\mathrm{L}^{-1}( \pm 109.3)$ and a biomass of $1039.2 \mu \mathrm{g} \mathrm{L}-1( \pm 954.6)$.

Adults and copepodites of this species, experienced a density and biomass peak in April,with parameter values of 318.5 ind $\mathrm{L}^{-1}$ and $3029.1 \mu \mathrm{g} \mathrm{L}^{-1}$, respectively. 


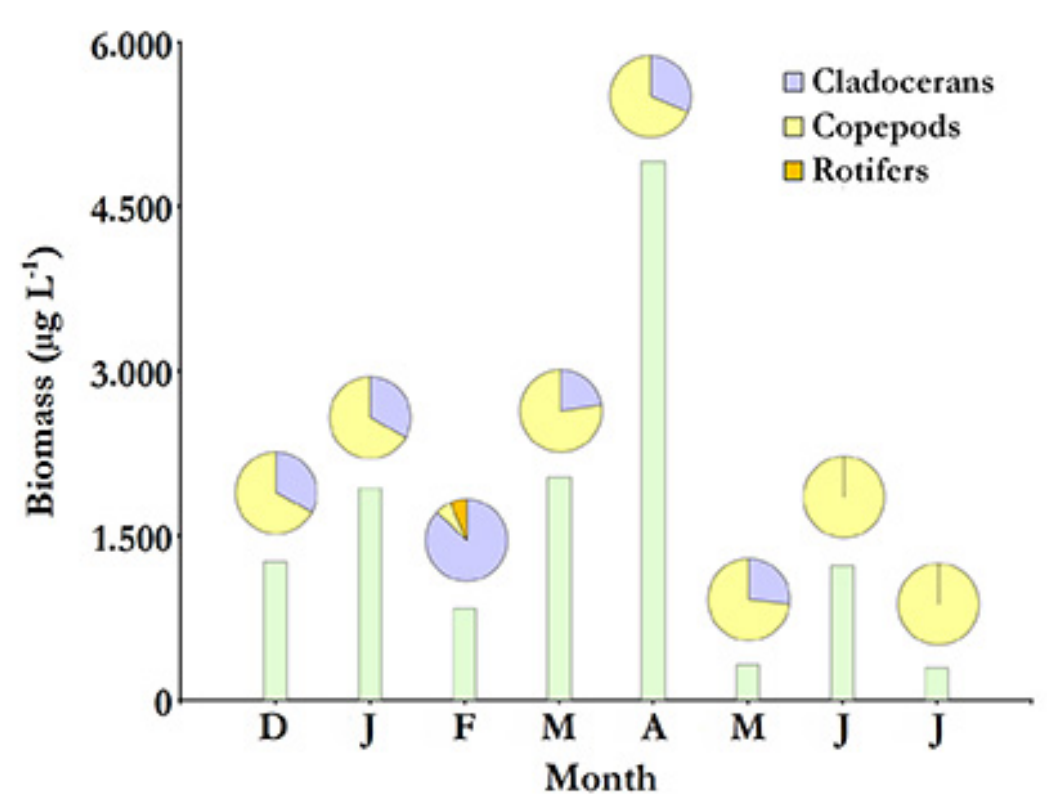

Figure 6. Total zooplankton biomass at each sampled month from December 2012 to July 2013 (bars) with relative contributions by taxonomic group (pie charts above bars) in the Ojo de Agua Uriburu lake.

Further, B. poopoensis was the sole copepod species present in the lake in June and July, and its nauplii larvae reached an average density and biomass of 133.56 ind $\mathrm{L}^{-1}( \pm 202.53)$ and $97.16 \mu \mathrm{g} \mathrm{L}^{-1}( \pm 149.41)$, respectively; experiencing a density and biomass peak in April that exceeded 473 ind $\mathrm{L}^{-1}$ and $352 \mu \mathrm{g} \mathrm{L}^{-1}$, respectively. These larvae accounted for $4.15 \%$ and $64.1 \%$ of the population density in January and March, respectively. However, no nauplii larvae were recorded in the last two sampled months.

Average body sizes of the two most important crustaceans in the studied lake, M. engeniae and B. poopoensis, increased following a similar pattern (Fig. 7). Between December and March, mean body lengths of $M$. engeniae and B. poopoensis were $803.4( \pm 27.4) \mu \mathrm{m}$ and $933.0( \pm 39.9) \mu \mathrm{m}$, respectively. In the subsequent months, larger average body sizes were observed. Specifically, M. engeniae individuals had an average size of $1020( \pm 84.2) \mu \mathrm{m}$ in May, and $B$. poopoensis, individuals reached an average body size in July of $1348.8( \pm 89.0) \mu \mathrm{m}$. M. engeniae individuals were last found in May 2013 (Fig. 7). 


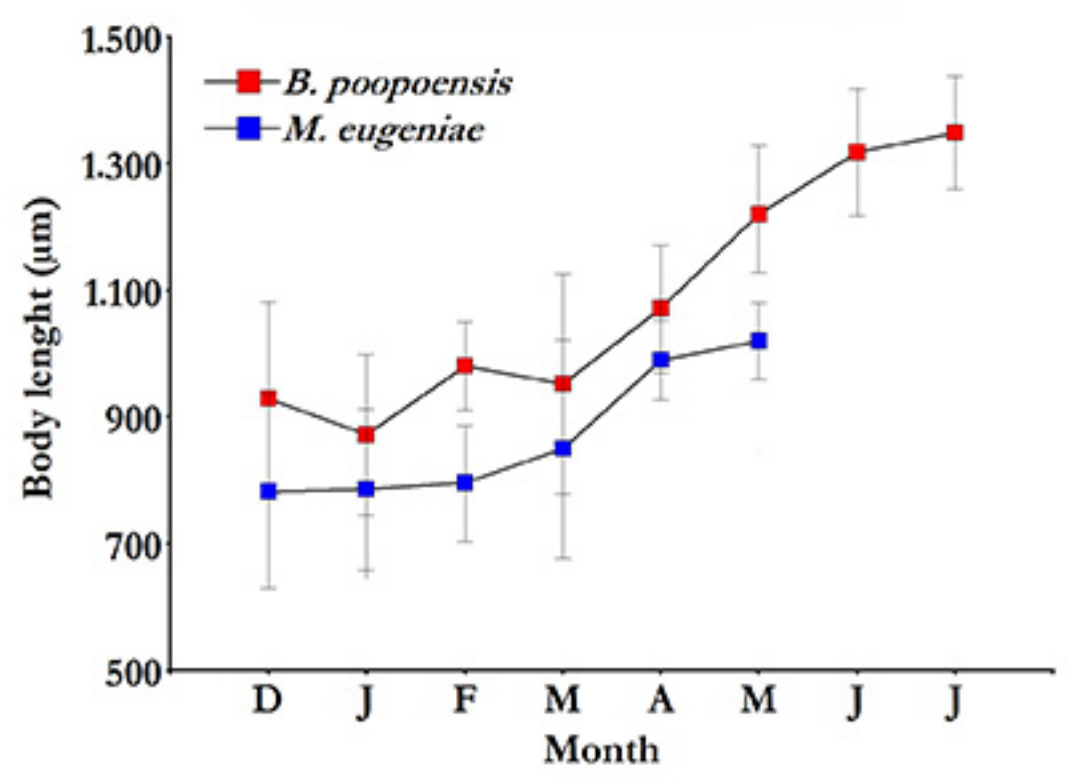

Figure 7. Variation in average body length of B. poopoensis and M. engeniae, the two most important crustaceans inhabiting the Ojo de Agua Uriburu lake throughout the study.

\section{Discussion}

Most shallow lakes in the province of La Pampa are temporary, and their filling and drying depends on wet and dry climatic cycles (Viglizzo, 2010). These lakes are filled during rain cycles, associated with the El Niño southern oscillation phenomenon, with starting hydroperiods of variable duration. In a relatively prolonged hydroperiod (with greater-than-average precipitation) the amount of water stored in the soil increases and the piezometric level rises. Groundwater discharges in low-lying areas, where temporary lakes are located, constitute the main water source for these lakes, followed in importance by rain water or surface runoff (Dornes et al. 2016).

Ultimately, hydroperiod duration in these lakes is closely related to the amount of water stored in the ground and may extend for several years in some cases; water input from rain may not be constant, but phreatic water discharges keep the water influx into the lake (Echaniz et al. 2013a; b). The Ojo de Agua Uriburu lake remained filled for at least ten years, dried completely after July 2013, and was filled again by end of 2015 due to the beginning of a new period of abundant rainfall (Vignatti \& Echaniz, pers. obs.). 
Previous to its latest drying event, the Ojo de Agua Uriburu lake was rich in chloride - carbonate (sodic), and the hardness of its water was reduced given the low concentrations of bivalent cations. At the beginning of the present study, the lake was classified as hyposaline (Hammer, 1986). However, only three months into the study (in March 2013), the process of salt concentration, consequence of water evaporation, drove the lake above the hypersaline threshold (Hammer, 1986). The lake remained hypersaline until drying. Because of these salinity changes, any classification of such lakes into a specific category is of relative utility, and caution should be taken, as salinity depends on the ruling hydroperiod at the time of observation. Both chemical composition and salt concentration analyses confirmed that the lake chemistry was governed by evaporation - crystallization. This is the case for most lakes in the Central Chaco region of Argentina (Drago \& Quirós, 1995). Water transparency was relatively low, likely due to the high amount of suspended solids, especially those of inorganic origin. This is a common situation for lakes in Central La Pampa. These lakes are located in flat landscapes, are of shallow depth, have relatively flat bottoms, are exposed to frequent winds, and commonly experience sediment resuspension from the bottom (Echaniz, 2010; Echaniz \& Vignatti, 2013; Echaniz et al. 2013a; Vignatti et al. 2012a). Remarkably, the lowest water transparency was recorded in April, when the highest concentration of phytoplankton chlorophyll-a coincided with a very high amount of suspended inorganic solids.

The observed high concentration of dissolved oxygen in the water, even when chlorophyll concentration was relatively low, could have been a consequence of atmospheric dissolution, favored by wind-driven turbulence, rather than a contribution of phytoplankton autotrophic organisms. This phenomenon is common in the clear lakes of La Pampa, such as El Carancho, Utracán, and La Amarga, where, despite the fact that chlorophyll-a concentrations are below $1.5 \mathrm{mg} \mathrm{m}^{-3}$, dissolved oxygen concentrations can be found above $9.5 \mathrm{mg} \mathrm{L}^{-1}$ (Vignatti et al. 2012b).

A particular characteristic of Ojo de Agua Uriburu is that winter water temperature was not as low as that in other shallow lakes in the region, where values below $6{ }^{\circ} \mathrm{C}$ have been recorded (Vignatti et al. 2012b; Vignatti \& Echaniz, unpublished data). This situation could be due to the large amount of inorganic, suspended solids rendering waters of an intense dark brown color and, in turn, favor heating by solar radiation. Similar conclusions have been drawn from the study of the Aime and Estancia Pey-Ma Lakes. These two lakes are similar to the Ojo de Agua Uriburu in their content of inorganic solids, color appearance, and recorded winter temperatures (above $9{ }^{\circ} \mathrm{C}$ ) (Vignatti et al. 2012a; Echaniz et al. 2013a). 
Zooplankton richness in Ojo de Agua Uriburu was low. However, this is common among fishless, saline lakes in Central A rgentina. These lakes are inhabited by the crustaceans B. poopoensis and $M$. engeniae and by the rotifers Hexarthra fennica and Brachionus plicatilis (Vignatti, 2011; Vignatti et al. 2012a; 2012b; 2016; Echaniz, 2010; Echaniz et al. 2006; 2013a; 2013b; 2015; 2016). Whereas these crustacean species are endemic to Neotropical halophilic lakes, the rotifers are cosmopolitan and are broadly distributed given their wide tolerance to salinity (Fontaneto et al. 2006; Echaniz et al. 2016).

Moina engeniae has, thus far, been found in hypo-mesosaline ranges, specifically in the Pey-Ma Lake, with a salinity level of $48 \mathrm{~g} \mathrm{~L}^{-1}$ (Echaniz et al. 2013a). Therefore, the present study provides the first record for this species in the hypersaline range. However, the observation that only females without eggs were found in hypersaline conditions may suggest that the reproduction of this species is affected by a high solute concentration, and that $M$. engeniae halotolerance is limited. Despite having been recorded as the most halotolerant Moinid in Argentina (Paggi, 1998), M. eugeniae tolerance is lower than that of other cogeneric species from other latitudes, such as Moina salina (Daday, 1888), observed in hypersaline waters of Mongolia, at a salinity of $61 \mathrm{~g} \mathrm{~L}^{-1}$ (Alonso, 2010), and North Africa, at a salinity of $225 \mathrm{~g} \mathrm{~L}^{-1}$ (Amarouayache et al. 2012).

Although increases in salinity can negatively influence zooplankton richness, density, and biomass, other factors such as eutrophication, changes in biotic interactions, and food availability should also be considered (El-Shabrawy et al. 2015). Since, throughout the study in Ojo de Agua Uriburu no predators were recorded and food availability (represented by phytoplankton chlorophyll-a) was always relatively high, the idea of a modulatory effect of salinity on the zooplankton community could be supported by the fact that richness was high while the lake remained in the mesosaline interval but declined once the lake surpassed the threshold of hypersalinity. Consequently, in the last two months of the sampling period, only the halotolerant $B$. poopoensis was found.

This decrease in richness is consistent with that recorded in the Great Salt Lake (USA), where four species were recorded when salinity was close to $50 \mathrm{~g} \mathrm{~L} \mathrm{~L}^{-1}$ but only one species was found when salinity was close to $250 \mathrm{~g} \mathrm{~L}^{-1}$ (Wurtsbaugh \& Berry, 1990); and in the Siberian Lake Chany, where an increase in salinity from $0.8 \mathrm{~g} \mathrm{~L}^{-1}$ to $6.4 \mathrm{~g} \mathrm{~L}^{-1}$ caused a decrease in zooplankton richness from 61 to 16 species (Kipriyanova et al. 2007). However, caution should be taken before reaching any conclusion, since the absence of significant statistical correlations among the studied environmental variables (water 
temperature and salinity), and the zooplankton parameters (density and biomass) is by no means a confirmation of a negative effect of increasing salinity on these biological parameters.

The largest mean body sizes for both $B$. poopoensis and M. engeniae were recorded in the final three months of the study; this period was marked by low temperatures and hypersalinity. Whereas in ectotherm vertebrates, individuals of small size are likely to occur at lower environmental temperatures (Gillooly et al. 2002; Ohlberger, 2013), in zooplankton animals, such as cladocerans (Havens et al. 2015) and copepods (Anufriieva \& Shadrin, 2014), larger body sizes have been registered at lower temperatures. In the present study, the observed increase in body size for $B$. poopoensis and $M$. eugeniae is a likely consequence of the stress produced by increased salinity rather than that of low temperatures (Herbst, 2001). Such an effect could be obtained by negatively influencing reproduction, as evidenced by the lack of ovigerous, parthenogenetic females of $M$. eugeniae, in May, and the absence of nauplii B. poopoensis larvae in June and July. Moreover, low temperature could not affect the reproduction of these two species, since ovigerous $M$. engeniae females were found throughout the winter months in two temporary saline lakes in 2006 (a period of relative hydrological stability) (Echaniz \& Vignatti, 2011; Echaniz et al. 2013b). In addition, in three mesosaline lakes of La Pampa, with relatively stable salinity, the highest population densities of $B$. poopoensis were recorded during the winter months, when a high proportion of nauplii and different stages of copepodites were found (Vignatti et al. 2016).

A feature of many shallow lakes of the region is that the combination of their temporary nature and their high salinity hinders their colonization by fish (Menni, 2004; Rosso, 2006). This situation, verified in Ojo de Agua Uriburu, may also lead to relatively large-sized zooplankton crustaceans, such as $B$. poopoensis and M. eugeniae.

Although phytoplankton richness can also decrease because of increased salinity, thus lowering the concentration of chlorophyll-a, the presence of $M$. engeniae could also too help to explain the low concentrations of chlorophyll- $a$ in this lake. Grazers are considered to play a key role in decreasing the amount of phytoplankton species of the genus Daphnia (Muylaert et al. 2006; Boveri \& Quirós, 2007; Echaniz et al. 2010). It is likely that, as a relatively large size grazer, M. engeniae had been contributing to keeping low phytoplankton levels in the lake (Echaniz, 2010). 
The environmental and biological changes that occur during lake drying have already been previously studied in two lakes of La Pampa. In comparison with the information obtained in the present study, variation in lake dynamics, due to differences in environmental conditions, can be highlighted. One of the previously studies lakes, El Guanaco, was subsaline, had a wide vegetation cover, showed a high biological richness ( 35 taxa), and hosted a species assemblage very different from that recorded in Ojo de Agua Uriburu, with rotifer predominance until complete drying (Echaniz \& Vignatti, 2010). The other lake, Aime, was hypo-mesosaline, but shared some characteristics with Ojo de Agua Uriburu, namely, reduced water transparency caused by resuspended sediments and total lack of vegetation (Vignatti et al. 2012a). Furthermore, there are important ecological differences between these three ecosystems. For instance; their different species richness and contrasting zooplankton density dynamics during their drying phases. In Ojo de Agua Uriburu, species richness was low, and density and biomass decreased when salinity exceeded $50 \mathrm{~g} \mathrm{~L}^{-1}$; whereas in Aime Lake, species richness was higher (16 taxa), salinity barely exceeded $23 \mathrm{~g} \mathrm{~L}^{-1}$; and zooplankton density experienced a peak, triggered by rotifers, exceeding a density of 29000 ind $\mathrm{L}^{-1}$.

This study is the first that documents the changes that occurred in an Argentine lake that reached hypersalinity. Comparison with existing data for other systems, confirms the remarkable variation in the ecology of saline lakes in the semiarid central region of Argentina. Therefore further studies are necessary to better understand the scarcely known ecological aspects of the filling and drying of a variety of water bodies, which may differ in their dynamics despite having similar characteristics.

\section{Conclusions}

The lakes in Central Argentina are temporary because they are strongly influenced by wet and dry climate cycles. Most of their ecological aspects have been studied during periods of relative stability; however, the dynamics that emerge as these lakes are being filled and dried constitute little studied scenarios of paramount interest.

The Ojo de Agua Uriburu lake, located in eastern La Pampa province, is in an arheic basin fed by phreatic inputs and rainfall. In December 2012, its depth was $0.7 \mathrm{~m}$ and its salinity was close to $16 \mathrm{~g} \mathrm{~L}^{-1}$. In July 2013, its depth decreased to $0.06 \mathrm{~m}$ and its salinity increased to above $92 \mathrm{~g} \mathrm{~L}^{-1}$ before the lake dried up completely. 
A total of six halotolerant species account for the zooplankton richness in the Ojo de Agua Uriburu Lake. Two of these six species, dominant in the lake, are the endemic, neotropical crustaceans Boeckella poopoensis and Moina engeniae.

Currently, only two other lakes in the region have been studied as they dry. Their salinity is lower and their species richness is higher. In the light of the present study, it is safe to assume that there is high variation in the ecology of saline lakes in the central region of Argentina. Therefore, establishing generalizations about their dynamics is relatively difficult, and more studies should be conducted on this topic.

\section{Conflict of interest}

The authors declare that this work does not present any conflict of interest.

\section{Acknowledgments}

The authors are thankful to the anonymous reviewers and editors for having substantially improved this manuscript with their comments and advice.

\section{References}

Adamowicz S, Hebert P, Marinone MC. Species diversity and endemism in the Daphnia of Argentina: a genetic investigation, Zoological Journal of the Linnean Society, (140): 171-205, 2004.

doi: $10.1111 /$ j.1096-3642.2003.00089.x

Alonso M. Branchiopoda and Copepoda (Crustacea) in Mongolian Saline Lakes, Mongolian Journal of Biological Sciences, 8(1): 9-16, 2010.

Amarouayache M, Derbal F, Kara MH. Note on the carcinological fauna associated with Artemiasalina (Branchiopoda, Anostraca) from SebkhaEzZemoul (Northeast Algeria), Crustaceana, 85(2): 129-137, 2012.

doi: 10.1163/156854012X623728

Anufrijeva V, Shadrin NV. Factors determining the average body size of geographically separated Arctodiaptomus Salinus (Daday, 1885) populations, Zoological Research, 35(2): 132-141, 2014.

doi: $10.11813 /$ j.issn.0254-5853.2014.2.132

APHA. Standard Methods for the Examination of Water and Wastewater. 18th edition. American Public Health Association (APHA), American Water Works Association (AWWA) and Water Pollution Control Federation (WPCF), Washington, DC. 1992.

Arar EJ. In Vitro Determination of Chlorophylls $a, b, c_{1}+c_{2}$ and Pheopigments in Marine And Freshwater Algae by Visible Spectrophotometry. Method 446.0. U.S. Environmental Protection Agency, 1997. 
Bayly IA. Invertebrate ocurrence and succesion after episodic flooding of a central Australian rock hole, Journal of Research Society Western Australian, 84: 29-32, 2001.

Belk D. Global Status and Trends in Ephemeral Pool Invertebrate Conservation: Implications for Californian Fairy Shrimp. In: Witham C, Bauder E, Belk D, Ferren Jr W, Ornduff R. editors. Ecology, conservation and management of vernal pool ecosystems. Proceedings from a 1996 Conference. California Native Plant Society, Sacramento, CA, 147-150, 1998.

Boveri M, Quirós R. Cascading trophic effects in pampean shallow lakes: results of a mesocosm experiment using two coexisting fish species with different feeding strategies, Hydrobiologia, 584: 215-222, 2007.

doi: 10.1007/s10750-007-0581-1

Culver D, Boucherle M, Bean D, Fletcher J. Biomass of freshwater crustacean zooplankton from length-weight regressions, Canadian Journal of Fisheries and Aquatic Sciences, 42(8): 1380-1390, 1985.

doi: $10.1139 /$ f $85-173$

Di Rienzo JA, Casanoves F, Balzarini MG, González L, Tablada MC, Robledo W. InfoStat (version 2010). GroupInfoStat, Facultad de Ciencias Agropecuarias, Universidad Nacional de Córdoba, Argentina, 2010.

Dornes P, Comas R, Cardín D, Pochetti R, Ianni J, Kruse E. Identificación y caracterización hidrológica de lagunas en el centro-este de la Provincia de La Pampa. In García R, Rocha V, Dornes P, editors. Relación Agua Subterránea-Superficial. Actas del IX Congreso Argentino de Hidrogeología - VII Seminario Hispano Latinoamericano de Hidrología Subterránea, San Fernando del Valle de Catamarca, 213-220, 2016.

Drago E, Quirós R. The hydrochemistry of inland waters of Argentina; a review, International Journal of Salt Lake Research, 4: 315-325, 1995.

doi: $10.1007 / \mathrm{BF} 01999115$

Echaniz S. Composición y abundancia del zooplancton en lagunas de diferente composición iónica de la provincia de La Pampa. Tesis Doctoral. Facultad de Ciencias Exactas, Físico Químicas y Naturales, Universidad Nacional de Río Cuarto. 169 p. 2010.

Echaniz SA, Vignatti AM, José de Paggi S, Paggi JC, Pilati A. Zooplankton seasonal abundance of South American saline shallow lakes, International Review of Hydrobiology, 91(1): 86-100, 2006.

doi: 10.1002/iroh.200510803

Echaniz S, Vignatti A. Diversity and changes in the horizontal distribution of crustaceans and rotifers in an episodic wetland of the central region of Argentina, Biota Neotropica, 10(3): 133-141, 2010.

doi: 10.1590/S1676-06032010000300014

Echaniz SA, Vignatti AM, José de Paggi SB, Cabrera GC. El modelo de estados alternativos de lagos someros en La Pampa: comparación de Bajo de Giuliani y El Carancho. Libro del $3^{\circ}$ Congreso Pampeano del Agua, 45-53, 2010. 
Echaniz SA, Vignatti AM. Seasonal variation and influence of turbidity and salinity on the zooplankton of a saline lake in central Argentina, Latin American Journal of Aquatic Research, 39(2): 306-315, 2011.

doi: 10.3856/vol39-issue2-fulltext-12

Echaniz SA, Vignatti AM, Cabrera GC, José de Paggi SB. Zooplankton richness, abundance and biomass of two hypertrophic shallow lakes with different salinity, Biota Neotropica, 12(2): 37-44, 2012.

doi: 10.1590/S1676-06032012000200005

Echaniz SA, Vignatti AM. Trophic status of shallow lakes of La Pampa (Argentina) and its relation with the land use in the basin and nutrient internal load, Journal of Environmental Protection, 4: 51-60, 2013.

doi: 10.4236/jep.2013.411A1007

Echaniz SA, Cabrera GC, Rodríguez C, Vignatti AM. Do temporary lakes vary from year to year? A comparison of limnological parameters and zooplankton from two consecutive annual cycles in an Argentine temporary saline lake, International Journal of Aquatic Science, 4 (1): 44-61, $2013 \mathrm{a}$.

Echaniz SA, Cabrera GC, Aliaga PL, Vignatti AM. Variations in zooplankton and limnological parameters in a saline lake of La Pampa, central Argentina, during an annual cycle, International Journal of Ecosystem, 3(4): 72-81, 2013b.

doi: $10.5923 /$ j.ije.20130304.03

Echaniz SA, Cabrera GC, Vignatti AM. The ecology of the saline lakes in the semiarid Pampa central (Argentina): limnological characterization and zooplankton of Utracán, Advances in Life Sciences, 5(3): 64-72, 2015. doi: $10.5923 /$ j.als.20150503.03

Echaniz S, Vignatti A, Cabrera G, Capecce C, Treffinger Cienfuegos MS. Comparación de los parámetros limnológicos y el zooplancton de un lago somero salino de La Pampa (Argentina) durante dos ciclos anuales de condiciones diferentes. Biología Acuática, 31: 28-39, 2016.

Eitam A, Blaustein L, Van Damme K, Dumont H, Martens K. Crustacean species richness in temporary pools: relationships with habitat traits, Hydrobiologia, 525: 125-130, 2004.

doi: 10.1023/B:HYDR.0000038859.51416.7d

El-Shabrawy G, Anufriieva E, Germoush M, Goher M, Shadrin N. Does salinity change determine zooplankton variability in the saline Qarun Lake (Egypt), Chinese Journal of Oceanology and Limnology, 33(6): 1368-1377, 2015. doi: org/10.1007/s00343-015-4361-x

EPA (Environmental Protection Agency). ESS Method 340.2: Total Suspended Solids, Mass Balance (Dried at 103 - $105{ }^{\circ} \mathrm{C}$ ) Volatile Suspended Solids (Ignited at 550 ${ }^{\circ} \mathrm{C}$ ). 1993.

Fontaneto D, De Smet W, Ricci C. Rotifers in saltwaters, re-evaluation of an inconspicuos taxon, Journal of the Marine Biological Association of the United Kingdom, 86: 623-656, 2006.

doi: $10.1017 /$ S0025315406013531 
Frisch D, Moreno-Ostos E, Green A. Species richness and distribution of copepods and cladocerans and their relation to hydroperiod and other environmental variables in Doñana, south-west Spain, Hydrobiologia, 556: 327-340, 2006.

doi: $10.1007 / \mathrm{s} 10750-005-1305-\mathrm{z}$

Gillooly JF, Charnov EL, West GB, Savage VM, Brown JH. Effects of size and temperature on developmental time, Nature, 417: 70-73, 2002.

doi: $10.1038 / 417070 \mathrm{a}$

Green J. Zooplankton associations in East African Lakes spanning a wide salinity range, Hydrobiologia, 267: 249-256, 1993.

doi: $10.1007 /$ BF00018806

Hall CJ, Burns CW. Responses of crustacean zooplankton to seasonal and tidal salinity changes in the coastal Lake Waihola, New Zealand Journal of Marine and Freshwater Research, 37(1): 31-43, 2003.

http://dx.doi.org/10.1080/00288330.2003.9517144

Hammer U. Saline Lake Ecosystems of the World. MonographiaeBiologicae 59. Dr. W. Junk Publishers, Dordrecht. 616 p. 1986.

Hammer $\varnothing$, Harper D, Ryan P. PAST: Paleontological Statistics Software Package for Education and Data Analysis, Palaeontologia Electronica, 4(1): 1-9, 2001.

Havens K, Motta Pinto-Coelho R, Beklioğlu M, Christoffersen K, Jeppesen E. Lauridsen T, Mazumder A, Méthot G, PinelAlloul B, Tavşanoğlu U, Erdoğan S, Vijverberg, J. Temperature effects on body size of freshwater crustacean zooplankton from Greenland to the tropics, Hydrobiologia, 743(1): 27-35, 2015.

doi: $10.1007 /$ s10750-014-2000-8

Herbst D. Gradients of salinity stress, environmental stability and water chemistry as a templet for defining habitat types and physiological strategies in inland salt waters, Hydrobiologia, 466: 209-219, 2001.

doi: 10.1023/A:1014508026349

Ivanova M, Kazantseva T. Effect of water $\mathrm{pH}$ and total dissolved solids on the species diversity of pelagic zooplankton in lakes: a statistical analysis, Russian Journal of Ecology, 37(4): 264-270, 2006.

doi: 10.1134/S1067413606040084

Jenkins DG, Grissom S, Miller K. Consecuences of prairie drainage for crustacean biodiversity and metapopulations, Conservation Biology, 17: 158-167, 2003.

doi: 10.1046/j.1523-1739.2003.01450.x

Kalff J. Limnology. Inland Water System. Prentice Hall, New Jersey. 592 p. 2002.

Kipriyanova LM, Yermolaeva NI, Bezmaternykh DM, Dvurechenskaya SY, Mitrofanova EY. Changes in the biota of Chany Lake along a salinity gradient, Hydrobiologia, 576(1): 83-93, 2007.

doi: 10.1007/s10750-006-0295-9 
Mann KH. Inland water ecosystem. In Enciclopædia Britannica editors, 2002.

McCauley E. The estimation of the abundance and biomass of zooplankton in samples. In: Downing J, Rigler F, editors. A manual on methods for the assessment of secondary productivity in freshwaters. Second edition. Blackwell Scientific Publications, Oxford, 228-265, 1984.

McCulloch G, Irvine K, Eckardt F, Bryant R. Hydrochemical fluctuations and crustacean community composition in an ephemeral saline lake (Sua Pan, Makgadikgadi Botswana), Hydrobiologia, 596(1): 31-46, 2007. doi: $10.1007 /$ s10750-007-9055-8

Menni RC. Peces y ambientes en la Argentina continental. Ed. Museo argentino de ciencias naturales, Buenos Aires. 314 p. 2004.

Meybeck M, Kummu M, Dürr H. Global hydrobelts and hydroregions: improved reporting scale for water-related issues, Hydrology and Earth System Sciences, 17: 1093-1111, 2013.

doi: 10.5194/hess-17-1093-2013

Mura G, Brecciaroli, B. The zooplankton crustacean of the temporary waterbodies of the Oasis of Palo (Rome, central Italy), Hydrobiologia, 495: 93-102, 2003.

doi: 10.1023/A:1025406005367

Muylaert K, Declerck S, Van Wichelen J, De Meester L, Vyverman W. An evaluation of the role of daphnids in controlling phytoplankton biomass in clear water versus turbid shallow lakes, Limnologica, 36: 69-78, 2006. doi: 10.1016/j.limno.2005.12.003

Ohlberger J. Climate warming and ectotherm body size - from individual physiology to community ecology, Functional Ecology, 27: 991-1001, 2013. doi: $10.1111 / 1365-2435.12098$

Paggi J. Cladocera (Anomopoda y Ctenopoda). En Coscarón S, Morrone J, editores. Biodiversidad de Artrópodos Argentinos. Ediciones Sur, La Plata, 507-518, 1998.

Roshier DA, Whetton PH, Allan RJ, Robertson AI. Distribution and persistence of temporary wetland habitats in arid Australia in relation to climate, Austral Ecology, 26(4): 371-384, 2001.

doi: 10.1046/j.1442-9993.2001.01122.x

Rosso JJ. Peces pampeanos. Guía y ecología. Ed. L.O.L.A. (Literature of LatinAmerica), Buenos Aires. 223 p. 2006.

Ruttner-Kolisko A. Suggestions for biomass calculation of plankton rotifers, Archiv für Hydrobiologie-Beiheft Ergebnisse der Limnologie, (8): 71-76, 1977.

Schwartz SS, Jenkins DG. Temporary aquatic habitats: constraints and opportunities, Aquatic Ecology, 34: 3-8, 2000.

doi: 10.1023/A:1009944918152

Smith GR, Vaala DA, Dingfelder HA. Distribution and abundance of macroinvertebrates within two temporary ponds, Hydrobiologia, 497: 161-167, 2003. doi: $10.1023 / \mathrm{A}: 1025433103243$ 
Viglizzo EF. El agro, el clima y el agua en La Pampa semiárida: revisando paradigmas, Anales de la Academia Nacional de Agronomía y Veterinaria(ANAV) LXIV, 251-267, 2010.

Vignatti AM. Biomasa del zooplancton en lagunas salinas y su relación con la concentración de sales en ausencia de peces. Tesis Doctoral. Facultad de Ciencias Exactas, Físico Químicas y Naturales, Universidad Nacional de Río Cuarto. 220 p. 2011.

Vignatti A, Cabrera G, Echaniz S. Changes in the zooplankton and limnological variables of a temporary hypo-mesosaline wetland of the central region of Argentina during the drying, Pan American Journal of Aquatic Sciences, 7(2): 93-106, 2012a.

Vignatti A, Paggi JC, Cabrera G, Echaniz S. Zooplankton diversity and its relationship with environmental changes after the filling of a temporary saline lake in the semi-arid region of La Pampa (Argentina), Latin American Journal of Aquatic Research, 40(4): 1005-1016, $2012 \mathrm{~b}$.

doi: 103856/vol40-issue4-fulltext-16

Vignatti AM, Cabrera GC, Echaniz SA. Biology of Boeckella poopoensis Marsh, 1906 (Copepoda, Calanoida) in natural conditions in temporary saline lakes of the central Argentina, Biota Neotropica, 16(2): e20150063, 2016.

doi: 10.1590/1676-0611-BN-2015-0063

Wallace RL, Walsh EJ, Arroyo ML, Starkweather PL. Life on the edge: rotifers from springs and ephemeral waters in the Chiuahuan Desert, Big Bend National park (Texas, USA), Hydrobiologia, 546: 147-157, 2005. doi: 10.1007/s10750-005-4112-7

Waterkeyn A, Grillas P, Vanschoenwinkel B, Brendonck L. Invertebrate community patterns in Mediterranean temporary wetlands along hydroperiod and salinity gradients, Freshwater Biology, 53(9): 1808-1822, 2008.

doi: 10.1111/j.1365-2427.2008.02005.x

Williams DD. The ecology of temporary waters. Timber Press, Portland. 205 p. 1987.

Williams DD. Temporary water crustaceans: biodiversity and habitat loss. In Escobar-Briones E, Álvarez F, editors. Modern Approaches to the study of Crustacea, Kluwer Academic publishers, Dordrecht, 223-233. 2002.

Williams WD. Salinity as a determinant of the structure of biological communities in salt lakes, Hydrobiologia, 381(1): 191-201, 1998.

doi: 10.1023/A:1003287826503

World Meteorological Organization. International Glossary of Hydrology. United Nations Educational, Scientific and Cultural Organization, Geneva. 461 pp. 2012.

Wurtsbaugh WA, Berry TS. Cascading effects of decreased salinity on the plankton chemistry, and physics of the Great Salt Lake (Utah), Canadian Journal of Fisheries and Aquatic Sciences, 47(1): 100-109, 1990.

doi: 10.1139/f90-010

Zar JH. Biostatistical analysis. $3^{\circ}$ Ed. Prentice Hall, New Jersey. 988 p. 


\section{Cambios en el zooplancton y los parámetros ambientales durante la desecación de un lago salino temporal poco profundo en Argentina central}

Resumen. Argentina central tiene numerosos lagos salinos alimentados por fuentes de agua subterránea y agua de lluvia. Estos lagos son temporales y experimentan cambios significativos en el nivel de agua y la salinidad, de acuerdo con los ciclos climáticos de sequía y humedad. Este estudio pretende investigar las poco conocidas dinámicas del zooplancton y de los parámetros ambientales durante la fase de desecación de uno de estos lagos. Se tomaron muestras mensuales desde Diciembre de 2012 hasta Julio de 2013 en el lago "Ojo de Agua Uriburu", antes de su desecación. Al principio del estudio, la profundidad del lago fue de $0.7 \mathrm{~m}$ y su salinidad fue de $16.65 \mathrm{~g} \mathrm{~L}^{-1}$. Posteriormente, en Julio, su profundidad decreció a $0.06 \mathrm{~m}$ y su salinidad aumentó a $92.9 \mathrm{~g} \mathrm{~L}^{-1}$. La riqueza de especies de zooplancton fue baja (3 crustáceos y 3 rotíferos), con Boeckella poopoensis y Moina engeniae dominando el sistema. Estas dos especies alcanzaron la máxima densidad y biomasa en Abril (318.5 ind $\mathrm{L}^{-1}$ y $3029.1 \mu \mathrm{g} \mathrm{L}^{-1}$ en peso seco; 242.4 ind $\mathrm{L}^{-1} \mathrm{y}$ $1530.4 \mu \mathrm{g} L^{-1}$ en peso seco para B. poopoensis y $M$. eugeniae, respectivamente). No se encontró correlación ente estos dos parámetros y la salinidad. Las máximas longitudes corporales promedio para ambas especies se obtuvieron en los últimos meses de muestreo ( $M$. engeniae: $1020 \mu m \pm 84.2$ y B. poopoensis: $1348.8 \mu m \pm 89.0$ ). En este punto del estudio, no se encontraron estados larvales ni juveniles. El incremento en tamaño corporal es, posiblemente, el resultado del efecto en la reproducción causado por el incremento en la salinidad del sistema. Dado que el lago alcanzó un estado de hipersalinidad, sus dinámicas ecológicas son únicas en el conjunto de lagos temporales y salinos que se secan en Argentina Central. Se requieren estudios similares en otros ecosistemas temporales para aumentar la información sobre estos aspectos ecológicos poco conocidos.

Palabras clave: lagos temporales; lagos salinos; hidroperíodo; zooplancton; Boeckella poopoensis; Moina engeniae.

\section{Mudanças nos parâmetros ambientais e do zooplâncton durante a secagem de um lago temporário superficial salino no centro da Argentina}

Resumo. No centro da Argentina há inúmeros lagos salinos que são alimentados por aportes freáticos e precipitações. Estes lagos são temporários e sofrem alterações significativas do nível de água e salinidade, relacionados com ciclos climáticos úmidos e secos. O objetivo deste estudo foi investigar a dinâmica pouco conhecida dos parâmetros ambientais e do zooplâncton durante a fase de secagem de um desses lagos. As amostras foram coletadas mensalmente entre dezembro de 2012 a julho de 2013 no lago "Ojo de Agua Uriburu", antes da secagem do mesmo. No início do estudo, a profundidade do lago foi de $0.7 \mathrm{~m}$ e a salinidade foi de $16.65 \mathrm{~g} \mathrm{~L}^{-1}$, mais tarde, em julho, sua profundidade diminuiu para $0.06 \mathrm{~m}$ enquanto a salinidade aumentou até $92.9 \mathrm{~g} \mathrm{~L}^{-1}$. A riqueza de espécies do zooplâncton foi baixa (três crustáceos e três rotíferos), com predomínio de Boeckella poopoensis Marsh, 1906 e Moina engeniae Olivier, 1954 no sistema. A densidade máxima e biomassa foram atingidas pelas duas espécies dominantes em abril (318.5 ind $L^{-1}$ e $3029.1 \mu g L^{-1}$ de peso seco, e 242.4 ind $L^{-1}$ e $1530.4 \mu g L^{-1}$ de peso seco, para B. poopoensis e $M$. eugeniae, respectivamente), e não foi encontrada correlação entre ambos os parâmetros e a salinidade. O comprimento médio máximo do corpo para ambas as espécies foi observado nos últimos meses de amostragem (M. engeniae: $1020 \mu \mathrm{m} \pm 84.2$ e B. poopoensis: $1348.8 \mu \mathrm{m} \pm$ 89.0). Neste ponto do estudo, não foram evidenciados estágios juvenis nem larvais. O aumento do tamanho médio do corpo é, possivelmente, devido a um efeito negativo da salinidade na reprodução. Dado que este lago atingiu a hipersalinidade, sua dinâmica ecológica é única entre as dinâmicas dos outros lagos salinos temporários que secaram no centro da Argentina. Estudos semelhantes em outros ecossistemas temporários são necessários para aumentar a informação sobre estes aspectos ecológicos pouco conhecidos.

Palavras-chave: lago temporário; lago salino; hidroperíodo; zooplâncton; Boeckella poopoensis; Moina engeniae. 


\section{Alicia M. Vignatti}

Is currently professor of animal physiology at Universidad Nacional of La Pampa and obtained her Doctoral degree in Biological Sciences at Universidad Nacional of Río Cuarto. Her research area entails ecophysiology of planktonic crustaceans from epicontinental ecosystems and ecology of shallow, saline, and temporary lakes

\section{Gabriela C. Cabrera}

Is currently assistant professor of animal physiology at Universidad Nacional of La Pampa and obtained her Doctoral degree in Biological Sciences at Universidad Nacional of Mar del Plata. Her research area includes ecophysiology of planktonic crustaceans from epicontinental ecosystems and ecology of shallow, saline, and temporary lakes.

\section{Maila Canosa}

Is an undergraduate student of Ingeniería en Recursos Naturales y Medio Ambiente at Universidad Nacional of La Pampa and is currently preparing his graduation thesis.

\section{Santiago A. Echaniz}

Is professor of biology at Universidad Nacional of La Pampa and obtained his Doctoral degree in Biological Sciences at Universidad Nacional of Río Cuarto. His research area is ecophysiology of planktonic crustaceans from epicontinental ecosystems and ecology of shallow, saline, and temporary lakes. 